\title{
Acclimatization Process on Hybrid Upflow Anaerobic Sludge Blanket Reactor (HUASBR) using Bioball as Growth Media with OLR Variation for Treating Tofu Wastewater
}

\author{
NYIMAS YANQORITHA ${ }^{1,2}$, MUHAMMAD TURMUZI $^{1}$, IRVAN $^{1 *}$, FATIMAH BATUBARA $^{1}$ and ILMI ${ }^{3}$ \\ 1'Department of Chemical Engineering, Universitas Sumatera Utara, Jalan Almamater Kampus USU, \\ Medan, 20155, Indonesia. \\ 2Department of Chemical Engineering, Institut Teknologi Medan, Jalan Gedung Arca 52, Medan, 20217, Indonesia. \\ ${ }^{3}$ Department of Mechanical Engineering, Institut Teknologi Medan, Jalan Gedung Arca 52, Medan, 20217, Indonesia. \\ *Corresponding author E-mail: irvan@usu.ac.id
}

http://dx.doi.org/10.13005/ojc/340654

Received: July 02, 2018; Accepted: November 01, 2018)

\begin{abstract}
Wastewater of tofu industry contains very high organic content, then anaerobic process is the most suitable for degrading this liquid waste. The hybrid upflow anaerobic sludge blanket reactor (HUASBR) was applied in this study because it has the advantage in ensuring good contact between biomass and substrate where a suspension medium and anaerobic filter are able to withstand more biomass in the attached media. Processing Anaerobic process is carried out with the help of bacteria where bacteria need seeding and acclimatization. Acclimatization is the process of adaptation of microorganisms to wastewater to be treated. This adaptation process is carried out by adding waste water from the smallest concentration to the actual concentration. The purpose of this study is to determine the effect of variations in organic load rate (OLR) on the acclimatization process in removing $\mathrm{COD}$, biogas production in accordance with the $\mathrm{pH}$ of the anaerobic degradation process so that the optimal process of the acclimatization process can be obtained. In this study, the acclimatization process took 200 days with variation of OLR in the range of $1.5-5.9 \mathrm{~kg} \mathrm{COD} \mathrm{m}^{-3} \mathrm{~d}^{-1}$ at HRT $24 \mathrm{~h}$ and flow rate up (Vup) of $0.08 \mathrm{~m} / \mathrm{h}$. The objective of OLR variation was to evaluate acclimatization process on the HUASBR performance during process optimization. The highest biogas production and removal efficiency of $\mathrm{COD}$ were achieved in $\mathrm{pH}$ range of 6.5-7.6. while, the highest COD removal efficiency obtained was $86.57 \%$ on the $140^{\text {th }}$ day and biogas production $7700 \mathrm{ml}$ for OLR $4.8 \mathrm{~kg}$ COD $\mathrm{m}^{-3} \mathrm{~d}^{-1}$ at HRT 24 hours. Consequently, the optimum OLR for treating the tofu wastewater could be achieved up to $4.8 \mathrm{~kg} \mathrm{COD} \mathrm{m}^{-3} \mathrm{~d}^{-1}$ and HRT 24 hours.
\end{abstract}

Keywords: Acclimatization, Tofu wastewater, HUASBR, Biogas, Waste water.

\section{INTRODUCTION}

Development of industrial wastewater treatment technology is growing day by day.
Among them, anaerobic processing is considered as the promising method because it has several advantages such as: able to degrade high organic loads, producing biogas that can be used as energy

This is an Open Access article licensed under a Creative Commons license: Attribution 4.0 International (CC- BY). Published by Oriental Scientific Publishing Company @ 2018

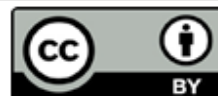


source, low energy, high efficiency, produce little sludge, low operating cost, no need large area, easy in operation, require little nutrient ${ }^{1,3}$.

Tofu industry is one of the industries in Indonesia which its effluent can pollute the environment. The appropriate process to treat tofu wastewater is anaerobic process. Waste generated from the tofu mills is in the form of viscous liquid, separated from a clump of so-called whey water. Tofu wastewater has COD content in the range of 7520-11450 mg/L which still contains high concentration of protein ${ }^{4}$.

Anaerobic processes are grouped by suspended growth processes and embedded growth processes. One of the reactors using the growth of suspended microorganisms is the upflow anaerobic sludge blanket (UASB). Anaerobic process with UASB reactor gives the advantage to be applied commercially and the effluent can fulfil the standard regulation of Indonesian government. The characteristics of UASB reactor are capable of operating at very high load rates with sludge produced easily settled, high biomass concentrations $(30,000-80,000 \mathrm{mg} / \mathrm{L})$ and excellent solid and liquid separations ${ }^{2}$.

The UASB reactor has been developed which known as the hybrid UASB reactor. The HUASBR is an improved version of the UASB system that combines with fixed film reactors ${ }^{3}$.

The HUASBR is an attractive alternative technology for treating various types of wastewater such as sago, tofu, refinery, starch, and milk wastewater. The acclimatization process in HUASBR using PVC rings as growth media for treating tofu wastewater, bacteria started to work on the $50^{\text {th }}$ day, shown by the formation of biogas and efficiency of COD removal of $67.21 \% 5$.

Acclimatization process for 80 days on HUASBR in processing spent wash distillery having COD load of $162,000 \mathrm{mgL}^{-1}$ is able to remove COD up to more than $95 \%$ and lots of biogas produced with variations of organic loading rate (OLR) about 0.25 - $2.30 \mathrm{kgCODm}^{-3} \mathrm{~d}^{-1}$ at optimal hydraulic retention time at 24 hours ${ }^{6}$.
In sago industry, anaerobic technology using the HUASBR is an effective method to treat its waste with COD removal up to $95 \%$, with production of methane. The HUASBR can support higher concentration of biomass than UASB reactor, because HUASBR has supporting media as attached system in HUASBR ${ }^{7}$. Also, in refinery waste treatment, it was obtained that COD removal efficiency was $87.35 \%$ and biohydrogen production rate was $1300 \mathrm{~mL} /$ day $^{8}$.

Anaerobic hybrid reactors can tolerate high COD concentrations where the removal efficiency of COD is $50-94 \%$ using an anaerobic hybrid reactor in liquid waste treatment under various OLRs between 0.45 and $32 \mathrm{kgCODm}^{-3} \mathrm{~d}^{-19}$.

In operational conditions, organic loading rate (OLR) is one of the important parameter ${ }^{7,10}$.

In processing milk wastewater with OLR until $8.9 \mathrm{~kg} \cdot \mathrm{m}^{-3} \mathrm{~d}^{-1}$, COD removal could reach at about $93 \%$. Increasing OLR up to $15.7 \mathrm{~kg} \mathrm{COD} \mathrm{m}^{-3}$ $\mathrm{d}^{-1}$ provides modification of granular structure and loss of stability ${ }^{11}$.

The OLR has a significant influence on methane fermentation. In OLR $3.3-7.3 \mathrm{~kg}$ COD $\mathrm{m}^{-3} \mathrm{~d}^{-1}$ methane production increased sharply. When OLR decreased $4.8 \mathrm{~kg} \mathrm{COD} \mathrm{m}^{-3} \mathrm{~d}^{-1}$ methane production increased to $86.8 \%{ }^{12}$.

The increasing of OLR leads the decreasing of volatile solid and biogas production ${ }^{12,15}$.

Organic loading level that grow in the appropriate range can improve biogas production, then if OLR level is in the over range, it can cause system instability ${ }^{16}$. The aim of this study is to study the influence of OLR variations on acclimatization process on HUASBR using bioball as growth media for treating tofu wastewater.

\section{MATERIALS AND METHODS}

\section{Reactor HUASB}

The HUASBR was designed similar to the previous research which consists of suspended sludge blanket reactor, attached media and gas liquid solid separator (GLSS) ${ }^{15,17}$. The apparatus configuration is shown as Figure 1. 


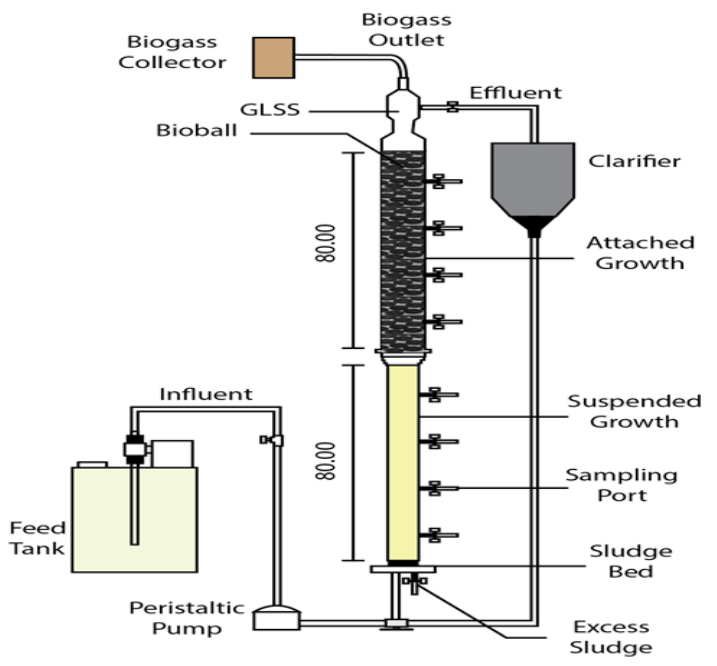

Fig. 1. Lab scale of Hybrid Upflow Anaerobic Sludge Blanket Reactor (HUASBR)

Operating volume of the reactor is 8.6 litres. Average of flow rate up (Vup) is $0.08 \mathrm{~m} / \mathrm{h}$. This reactor used bioball as support media. The system had four sample media ports suspended at the bottom of the reactor, four ports sampling attached at the top of the reactor and GLSS as a separator between gas, liquid and solids. Gas is collected through the gas valve provided on the top of the reactor. The amount of gas produced is indicated by the movement of water from the bottle because of the effect of the gas that has been collected in the bottle.

Tofu wastewater was discharged as an inlet and effluent is charges as an outlet at the top of the reactor which was connected to the clarifier as a waste tank. Tofu wastewater without further treatment was fed into the reactor through inlet pipe by the peristaltic pump. Packaging media as filter used in this study was bioball carrier. 167 pieces of black bioball were used as attached growth media of the same size which has a diameter of about 4 $\mathrm{cm}$, a specific area of $230 \mathrm{~m}^{2} / \mathrm{m}^{3}$, a porosity hollow of 0.92. Reactor was equipped with a gas-liquid-solid separator for separating effluent which increasing due to the movement of the feed.

\section{Sample Collection}

Tofu wastewater was obtained from one of the tofu mills in Medan, North Sumatera, Indonesia. Tofu wastewater contained organic load of COD $60,000 \mathrm{mg} / \mathrm{L}, \mathrm{NH}_{3}-\mathrm{N} 364 \mathrm{mg} / \mathrm{L}$ at $\mathrm{pH}$ range 3- 4. $\mathrm{NaHCO}_{3}$ and $\mathrm{K}_{2} \mathrm{HPO}_{4}$ were added to tofu wastewater to prevent $\mathrm{pH}$ fluctuation.

\section{Analytical Procedure}

The analytical procedures for all tests were carried out in accordance with the standard method for the examination of water and wastewater by American Public Health Association (APHA) ${ }^{18}$. Daily measurements were taken for the influent, port sampling, and effluent temperature, $\mathrm{pH}, \mathrm{COD}$, NH3-N and biogas production.

\section{RESULTS AND DISCUSSIONS}

Acclimatization process is a phase of adaptation of bacteria that has been attached to the liquid waste to be processed. Acclimatization process was conducted simultaneously with seeding process, where gradually adding substrate concentration started with small concentration up to the concentration of waste water to be processed. The goal of this process is to make bacteria get used to small concentrations first, if the lack of food concentration is increased step by step. In the bioreactor system, loading rate is part of the processing design. COD removal is related to the production of biogas and load rate to a reactor process related to the mass of methanogens immobilized therein.

\section{Performance of HUASBR}

The acclimatization process at HUASBR was conducted for 200 days at room temperature. HUASBR processing is a process of suspended system and is attached to a single reactor. Bioball as the growth of microorganisms was chosen because it has specific area, large porosity so as to attach large amounts of microorganisms. Therefore it enables to process industrial waste water with high concentration load that has considerable processing efficiency. The initial phase of acclimatization process was started at OLR of $1.5 \mathrm{~kg} \mathrm{COD} \mathrm{m}^{-3} \mathrm{~d}^{-1}$ and HRT 24 hours. OLR was increased gradually at a constant HRT of 24 hours. The highest biogas production and the highest COD removal efficiency were $7700 \mathrm{ml}$ and $86.4 \%$, respectively that accomplished on 4.8 $\mathrm{kg}$ of COD $\mathrm{m}^{-3} \mathrm{~d}^{-1}$ OLR at 140 days Figure 2.

pH during the acclimatization process of HUASBR

The $\mathrm{pH}$ of the industrial tofu waste was the range of 3-4, and was neutralized in the range of 6.5 
to 7.5 with the addition of $\mathrm{NaHCO}_{3}$. Fig. 3 shows $\mathrm{pH}$ influent and effluent process during acclimatization process. $\mathrm{pH}$ Influent range 5-7.5 while $\mathrm{pH}$ effluent of

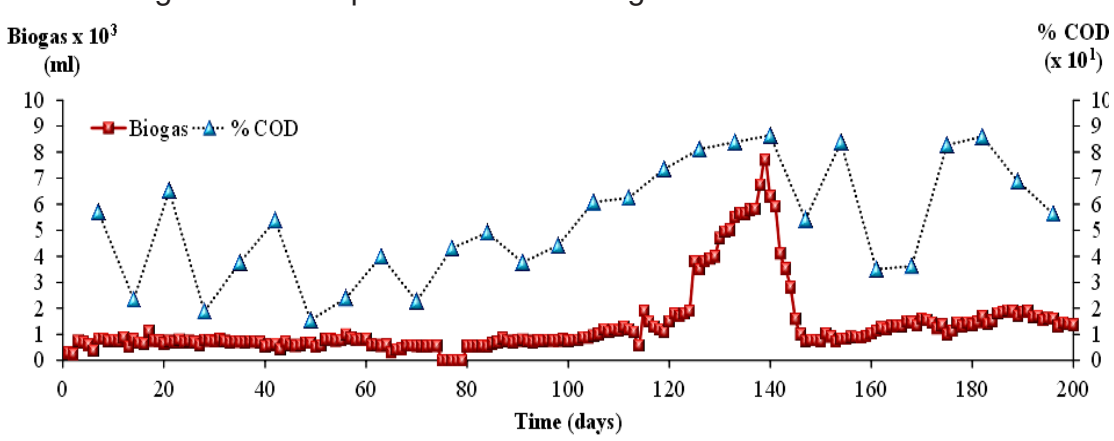

Fig. 2. Profile of biogas production and $\%$ COD removal on days operation

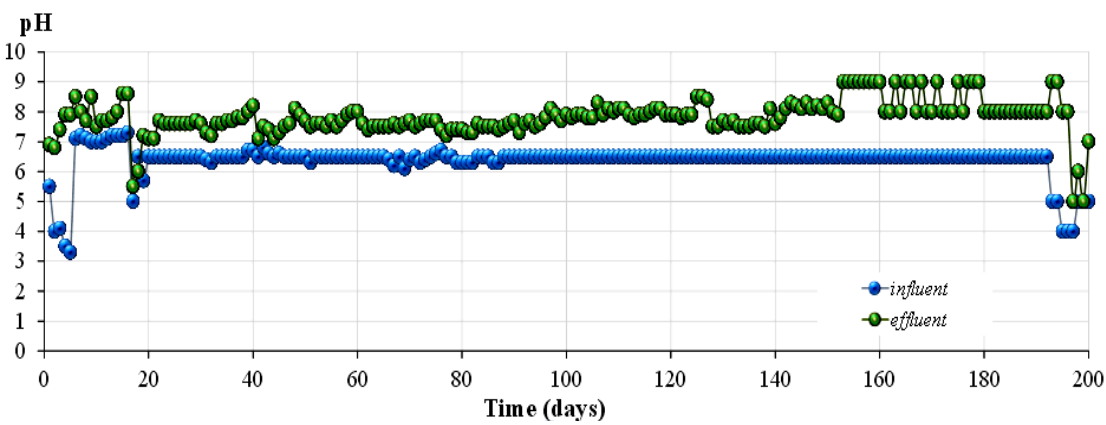

Fig. 3. Profile of pH influent and effluent on days operation

Bacteria of the hydrolysis phase, the acidogenesis phase require a $\mathrm{pH}$ condition of the range 5.5 to 7.0 and the methanogenetic phase bacteria require a $\mathrm{pH}$ condition of the range 6.5-8.0 ${ }^{19}$.

Figure 4 shows the OLR variation to $\mathrm{pH}$ effluent during the acclimatization process.

Figure 5 shows profile biogas production and \% COD removal during the acclimatization. Biogas production and removal efficiency of COD was highest on 140 days at $\mathrm{pH}$ range 6.5-7.6. The low $\mathrm{pH}$ in the process due to the rapid acidification process in the production of VFA on day ${ }^{17}$ at $\mathrm{pH}$ 5-5.5. Consequently the $\mathrm{pH}$ of the process must reactor range 5-8.3 at various concentration. $\mathrm{pH}$ of the methanogen process environment in bioreactors range from 6.5 to $8.2^{3}$. be regulated, so as not to inhibit the activity of methanogen bacteria. Wastewater of Tofu industry is a high-load organic compound which will increase alkalinity in bioreactor process ${ }^{5}$.

Due to the high protein content in industrial of tofu wastewater that ammonium concentration increased high which lead to the production of excess alkalinity indicated $\mathrm{pH} 9$ in 153 day process in addition of $100 \%$ substrate so that biogas production and COD removal decreased. Alkalinity in the bioreactor must be proportional because the disproportionate alkalinity will result in excessive $\mathrm{pH}$, shifting the concentration of ammonium equilibrium to the toxic.

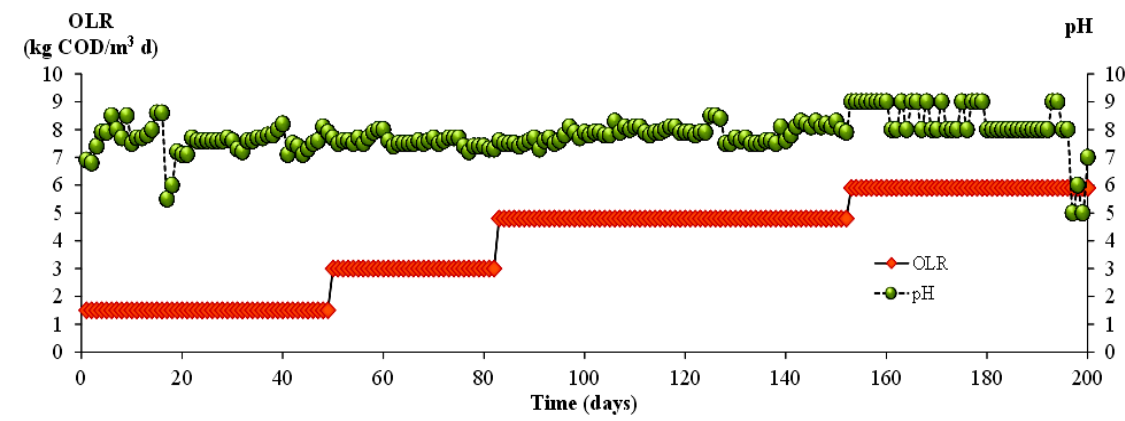

Fig. 4. Profile OLR to pH effluent on days operation 


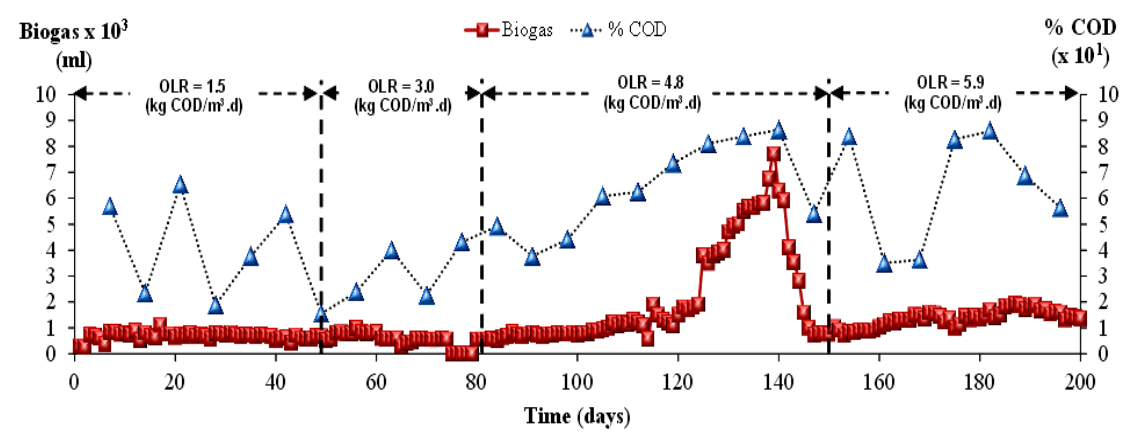

Fig. 5. Profile biogas production and \% COD removal on days operation

Variation of OLR on biogas production and $\%$ COD removal

OLR is one of the parameters that affect the process of wastewater treatment where the volumetric load rate is part of any processing in the bioreactor system. In this experiment, amount of OLR fed into the reactor was based on the values of HRT 24 hours. After the start-up, the OLR of the HUASB reactor were varied from 1.5 to $5 .{ }^{9} \mathrm{~kg}$ COD $\mathrm{m}^{-3} \mathrm{~d}^{-1}$. The objective of OLR variation is to evaluate

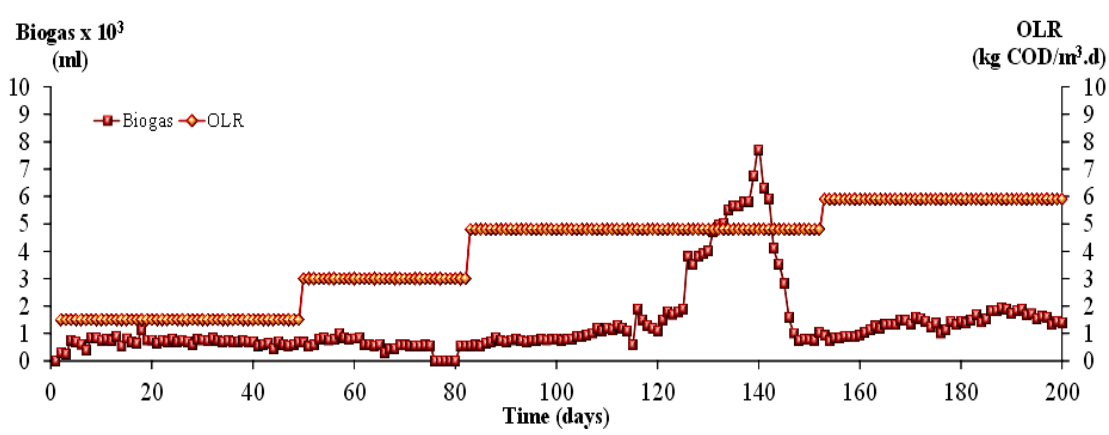

Fig. 6. Effect of OLR variation on Biogas production

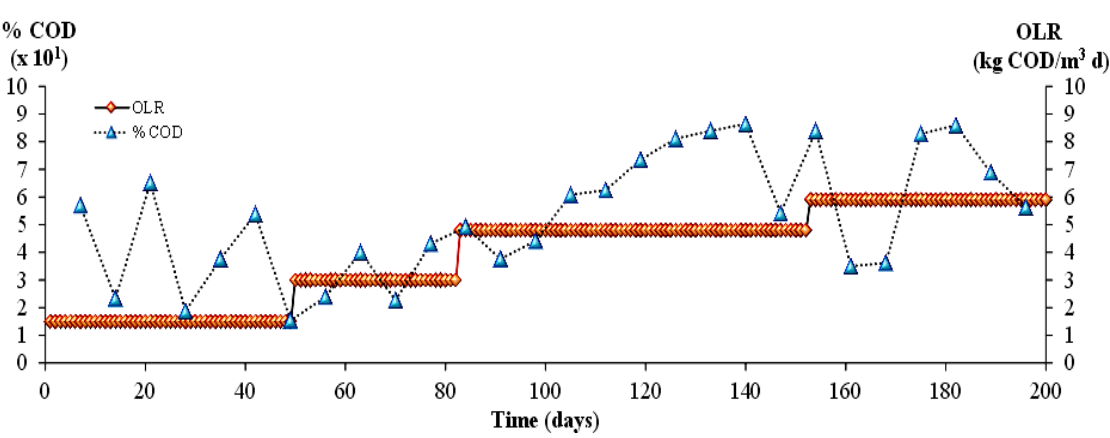

Fig. 7. Effect of OLR variation on \%COD removal

The acclimatization process was started with the addition of wastewater for the OLR of 1.5 $\mathrm{kg} \mathrm{COD} \mathrm{m}^{-3} \mathrm{~d}^{-1}$ at HRT $24 \mathrm{~h}$ up to 49 days where the highest biogas production is $1115 \mathrm{~mL}$ on the $18^{\text {th }}$ day and the highest COD removal efficiency is $53.79 \%$ on the $42^{\text {nd }}$ day. On day 50 , the OLR is raised to 3 the performance of the reactor during acclimatization process. In each OLR, the HUASB reactor was operated until a stable condition was reached so that the gas production and COD removal were constant. Fig. 6 shows the biogas production profile on the OLR variation and Fig. 7 shows \% COD removal on the OLR variation. Measurement of biogas production was conducted everyday during acclimatization process. 
of Tofu wastewater. In this OLR phase during $\mathrm{pH}$ acclimatization process was in the range of 6.5-8.5. Biogas production and COD removal efficiency increased significantly to the highest level on day 140 i.e. $7700 \mathrm{ml}$ and $86.41 \%$ respectively in the $\mathrm{pH}$ range 6.5-7.6. This indicated the process of acclimatization in this phase of methanogenic bacteria more active. Biogas production and COD removal efficiency up to 152 days decreased significantly. Therefore on the $153^{\text {th }}$ day the concentration of industrial of tofu wastewater is added to $100 \%$ for the OLR $5.9 \mathrm{~kg}$ COD $\mathrm{m}^{-3} \mathrm{~d}^{-1}$. In this phase of OLR, the highest COD removal efficiency is $85.96 \%$ on 182 days while biogas $1690 \mathrm{~mL}$ in the $\mathrm{pH}$ range 5-9. In this phase $100 \%$ wastewater concentration should not be added $\mathrm{NaHCO}_{3}$ because the characteristics of tofu wastewater containing high ammonia can inhibit the activity of methanogen bacteria capable of working in the $\mathrm{pH}$ range $6.5-8.2^{3}$.

\section{CONCLUSION}

Increased biogas yield and COD removal efficiency are affected by the OLR in the right range.
To achieve high OLR, the dilution of wastewater into the system must be through a relatively shorter HRT whereas the tofu wastewater is a pollutant complex that requires a long hydrolysis process time. ${ }^{3}$ Therefore industrial of tofu wastewater requires longer proportional HRT to achieve a given loading rate. The optimal organic loading rates (OLR) for treating the tofu wastewater was up to $4.8 \mathrm{~kg}$ COD $\mathrm{m}^{-3} \mathrm{~d}^{-1}$ and HRT 24 hours. The highest COD removal efficiency was $86.41 \%$ and biogas production 7700 $\mathrm{mL}$ on the $140^{\text {th }}$. The loading capacity limit was observed when the OLR was further upgraded to $5.9 \mathrm{~kg} \mathrm{COD} \mathrm{m}^{-3} \mathrm{~d}^{-1}$.

\section{ACKNOWLEDGMENT}

The author's gratefully acknowledge the financial support from Ministry of Research of Technology and Higher Education (Kemenristekdikti) on Indonesia through Research Strategic National (PSN) 2018, Institute Technology Medan (ITM) and Department of Chemical Engineering of Doctor Program of Universitas Sumatera Utara.

\section{REFERENCES}

1. Irvan, Trisakti, B., Maulina, S., and Daimon, H., Rasayan J. Chem., 2018, 11(1), 378-385.

2. Grady, C.P.L., Daigger, G.T., Lim, H.C., "Anaerobic Processes," Marcel Dekker., 1999.

3. Speece, R.E., "Introduction, Biomass Immobilization," Vanderbilt University., 1996.

4. BPPT, "Analysis of Existing Condition for Biogas Tech Implementation in Tofu Wastewater Treatment," Renewable EnergyEfficiency Energy Partnership (REEEP) Env. Tech. Centre, The Agency for the Assessment and App. of Tech., 2013.

5. Yanqoritha, N., Turmuzi, M., Derlini, AIP Conf. Proceedings, 1840, 110013., 2017.

6. Thiyagu, R., and Sivarajan, P., Int. Quarterly Scientific J. of Nature Env. and Pollution Tech., 2018, 17(1), 223.

7. Govindaradjane, S., Sundarajan, T., Int. J. of Eng. Adv. Tech., 2013, 2(4), 55.

8. Sridevi, K., Sivaraman, E., Mullai, P., Bioresource Tech., 2014, 165, 223.

9. Azhar, N., Tutuk, F., Keskin, T., Int. Biodeterioration and Biodegradation., 2009 63, 690.

10. Li, Y.F., Abraham, C., Nelson M.C., Chen, P.H., J.
Graf, Z. Yu, Environ. Biotech., 2015 99, 8777.

11. Hu, Y., Kobayashi, T., Qi, W., Oshibe, H., Xu, K., Waste Management, 2018, 74, 150.

12. Gomes, D.R.S., Papa, L.G., Cichello, G.C.V., Belancon, D., Pozzi, E.G., Balieiro, J.C.C., Monterrey, E.S., Tommaso, G., Desalination., 2011, 279, 96.

13. Babaee, A., Shayegan, J., Bioenergy Tech (BE), World Renewable Energy Congress Sweden., 2011, 411.

14. Aramrueang, N., Rapport, J., Zhang, R., Biosystems Eng., 2016, 147, 174.

15. Adebayo, A.O., Jekayinfa, S. O., Linke, B., British J. of Applied Science \& Tech., 2015 ., 11(4), 1.

16. Sun, M.T., Fan, X.L., Zhao, X. X., Fu, S. F., Manasa, M.R.K., Guo, R. B., Bioresource Tech., 2017, 235, 292.

17. Yanqoritha, N.,Turmuzi, M., Irvan, Fatimah, Derlini, Orient. J. Chem., 2018, 34(3), 1653.

18. APHA, Standard methods for the examination of water and wastewater 22nd ed, Washington (DC, USA): American Public Health Association., 2012.

19. Dobre, P., Nicole, F., Matei, F., Romanian Biotechnological Letters., 2014, 19(3), 9283. 